\title{
Editorial: Transnational Youth Mobilities: Emotions, Inequities, Temporalities
}

Population, Space and Place

Ruth Cheung Judge, Matej Blazek and James Esson

\section{Abstract}

This editorial outlines a research agenda for critical exploration of transnational youth mobilities centred on three concepts: emotions, inequity, and temporality. This agenda offers novel perspectives on the interplay between geographies of social difference and the multiscalar forces governing and being made through mobility. Emotions advance theorisations of agency by providing a generative lens to examine how aspirations, social relationships, and political subjectivities intersect to inform young people's lifeworlds and mobilities. Critical analyses of how youth navigate challenging structural conditions are shown to be sharpened by considering the mutually constitutive nature of inequity and (im)mobility. A temporal lens reveals how youth mobilities are driven, experienced, and shaped by structural and social dynamics including, but not limited to, precarity, border regimes, and intergenerationality. We conclude by charting how further explorations into the diverse emotions and temporalities of youth mobility, centred on questions of inequity, can significantly advance scholarly debates within and beyond population geography.

\section{Introduction}

From the stark reality of youth taking risks to cross borders amid economic crisis or conflict, to the way mobility is leveraged to reproduce and enhance privilege across 
generations, young people's transnational mobilities are at the heart of contemporary social and political concerns. Geographers have found it fruitful to engage with both 'youth' and 'transnational mobility' as conceptual lenses into transitional processes. Exploring young people's contested and situated transitions from childhood to adulthood (Valentine, 2003; Hopkins and Pain, 2007) helps us to understand the 'frontline' of broader socioeconomic change and test taken-for-granted concepts such as 'agency' (Jeffrey, 2010 and 2013). Examining the transitions people make across space and state boundaries (Conradson and McKay, 2007; King, 2012) reveals how societies are being remade, demographically and socio-culturally. However, there is a need for greater theorisation of 'youth' and 'transnational mobility' together: the ways in which transnational mobility is a constitutive element of young lives and livelihoods, and how the diverse transitions between childhood and adulthood engender particular forms and modes of transnational mobility. This special issue aims to advance theorisations of how youth and transnational mobility relate, and contribute to research agendas on transnational mobility as a 'marker and maker of transitions for youth' (Robertson et al., 2018, 203).

We live in a globally interconnected world, where transnational mobility, networks and imaginaries are fundamental to young people's lives in even the most seemingly 'local' of contexts (Ansell, 2009; Honwana 2014; Jeffrey, 2010). At the same time, political debates and responses to migration, especially in the Global North, have taken on an increasingly exclusionary tone, and it is imperative not to romanticise young people's movement or give an impression of a 'borderless world' (Burridge, 2010; Wells, 2017). The papers in this issue, grounded in multiple and creative methodologies, and a wide range of geographical contexts, address the experiences of forced migrants and their children (Daniels et al., Evans), undocumented 
communities (Sirriyeh) and precarious youth whose agentive desires problematise categorisations of regular and irregular migrants (Esson). They also examine how transnational mobility is shaped by cross-generational economic crises, opportunities and meanings made around mobility (Ní Laoire), and nuance portrayals of the mobility of 'global elites' (Cranston). Thus, they provide critical analyses of how diverse transnational youth mobilities along the continuum between privilege and marginalisation produce, and are produced by, political and economic power dynamics in different contexts across the Global North and Global South.

Population geography is well positioned to explore these complex constellations of transnational youth mobility. This special issue extends two agenda-setting interventions published in Population, Space and Place. First, we draw on Holt and Costello's (2011) argument for centring mobility in research agendas concerning young people, and for a shift from macro perspectives on migration towards everyday geographies of mobility (as reflected in Leyshon, 2011; Danic, 2012). Second, the special issue responds to Findlay et al.'s (2015) call for more attention to the importance of mobility in the life-course, as part of a shift from demographic perspectives on migration towards a mobility approach that understands movement alongside meanings embedded in intersectional identities of gender, class and race and associated power relations (Adey, 2006; Cresswell, 2010).

Several of the papers in the special issue emphasise processes of mobilisation and immobilisation in order to advance theoretical explorations of the interplay between geographies of social difference and the multi-scalar forces governing and being made through mobility. In line with Holt's and Costello's (2011) intervention, such an embedded approach foregrounds the question of agency, and how it is constituted 
through the ways mobility alters temporal and place-specific relationships.

Furthermore, the special issue centres transnational mobility of youth - understood as a geographically, culturally and historically contingent category distinct from childhood or adulthood - beyond more generalized explorations of the mobility of children or families (Barker et al., 2009; Ní Laoire et al., 2010; Tyrell et al., 2012),. In doing so, it pushes forward the theorisation of the co-constitutive relationship between transnational (im)mobility and youthful populations. For instance, critical examinations of young people's 'spatial mobility and social becoming' (Esson, 2015a) enable us to analyse the place- and time-specific ways in which transnational mobility is constituted by interscaled forces which mobilise and immobilise particular populations (Cranston, Sirriyeh, Esson); and the ways in which transnational mobility constitutes shifts in intergenerational relations (Daniels et. al., Ní Laoire) or in senses of national and cultural belonging (Evans).

In this editorial, we propose three conceptual directions to advance the theorisation of the relationship between youth and transnational mobilities: emotions, inequities, and temporalities. While these themes are generating fruitful scholarship in the studies of migration (Boccagni and Baldassar, 2015; Griffiths et al., 2013; Bauböck, 2009) and young people (Blazek and Windram-Geddes, 2013; Uprichard, 2008; Pilkington and Johnson 2003), there is further scope to examine them as centrally constitutive to transnational youth (im)mobilities. These themes run - in explicit and implicit ways - throughout the papers in this special issue. In the remainder of this editorial, we elaborate on the potential we see in each of these conceptual directions.

\section{Emotions}


Emotions offer insight into young people's identities, practices, imaginations, aspirations, social relationships and political subjectivities (Kraftl and Blazek, 2015). As such they can be seen as a generative lens to approach intersections of youth and transnational mobilities. It is legitimate to say that both movements across borders and amid stages of the life-course are often vividly felt, but emotions are more than just an additive layer in young people's migration experiences. As Chakraborty and Thambiah (2018) remind us, emotions are both expressive and instrumental in migration: they are manifestations of mobility experiences but they are also drivers behind young people's movement. Chakraborty and Thambiah (2018) indicate a link between the relative lack of attention to young people's emotions in migration and mobility studies and the under-theorisation of emotion more broadly:

"[T]here is a lack of engagement with children and young people's emotions and affectual realities often because emotions are implicitly subsumed rather than explicitly problematized or singularly inspected [...] They are often treated as an appendage to 'human nature' - something that is a reaction to the social/social realities rather than being constitutive of human interaction within these realities" (Chakraborty and Thambiah, 2018: 583)

Perhaps the most obvious theme where emotion is central to deepening our understanding of young people's lives and (im)mobilities is the issue of aspirations for the future, a notable theme in both work on youth (Brown, 2011) and migration (Carling and Collins, 2018). Imaginations of adult life are emotionally charged, bringing together tangible visualisations of future 
achievements together with an affective field of hopes, worries and insecurities (Brown, 2011). For young migrants the temporal uncertainty of the future intersects with the spatial and material uncertainty of new locations. Young people's localised and transnational mobilities have thus been framed as strategies to achieve respectable adulthood (Langevang and Gough, 2009; Esson, 2015a; Mains, 2007), as well as a more-than-strategic expressions of desires for adventure, thrill, status and pleasure (Ungruhe, 2010). As Collins et al. (2014) argue, aspirational visions of young migrants are not just attached to a manifested object (work opportunity, safety, reconnection with family members) but dispersed within emotional layers of vague expectations and unarticulated implications. Paying close attention to the constellations of fear as well as excitement before young people move (Khan, 2018) has scope to deepen understandings of young people's socio-cultural contexts, subjectivities and livelihoods beyond what they articulate as goals of movement.

Thus, the temporal and emotional dynamics in transnational youth mobility are more complex than just forward-oriented hopes, and young people's emotions can serve as a window to their social embeddedness. Future-hopes for mobility may be produced by and reinforce temporal-emotions of present 'stuckness' about painful socio-economic blockages to achieving life-course norms (Langevang and Gough, 2009, Esson, 2015a, Mains, 2007). Young people's decisions, strategies and experiences around mobility are shaped by emotional entanglements with their past and present at the point of departure (Crivello 2015). Furthermore, young people's emotions about movement are shaped by intergenerational relationships and imaginative geographies of belonging. Migrant children's multiple belongings are often a constitutive element of their 
identifications (Waite and Cook 2011, Evans this issue), and community memory work about parental homelands, including visits (Gardner and Mand, 2012; Wessendorf, 2007), may shape young people's sense of self. This includes elements of shame, guilt or pride about 'being away' (Tymczuk, 2013). Mobility experiences may entail the rupture of relations with a place, country, family and community, eliciting emotional registers ranging from anger and frustration, through shame and dissonance, to reaffirmation and reformation of love and compassion across distance (Baldassar 2015, Beazley et al. 2018, Francisco-Menchavez 2018, Sirriyeh this issue).

The significance of emotions in transnational youth mobilities also goes beyond the emotions of young migrants, as emotional responses to young people on the move and the politics that result are equally important. Amid social panic in the Global North about migration and the porosity of borders, bodies moving across space attract emotional responses that are highly aged, gendered and racialized (Pruitt et al. 2018). Young people's embodied subjectivities draw a spectrum of responses, from compassion to children as innocent victims of conflict (Hörschelmann, 2015) or deserving individualised 'dreamers' (Sirryeh, this issue) to a denial of sympathies, especially to young male migrants (McLaughlin, 2018; Esson this issue), as well as problematic demands that young migrants 'adapt' to the norms in destination contexts in order to receive state assistance (Daniel et al. this issue). Emotional responses to mobile young people do not only operate along the axis of national feelings about immigration, but are themselves shaped by intergenerational dynamics. Zembylas (2012), for instance, shows how young people in destination countries register emotional responses to young migrants which are both different from, but subsequently 
normalised by, the adult society. Elsewhere, Datta (2018) highlights how young people's 'success' in migration is itself perceived and appraised by their family members and communities, and migration 'failures' materialise into fissures in social relationships and powerful emotional experiences of shame and disappointment (cf. Daniels et al. this issue).

Finally, we contend that attention needs to be paid to the emotional agency of young people as they move. Murray and Mand (2013) argue that instances of mobility, whether everyday commuting (e.g. Porter et al. 2010) or large-scale transnational moves (Tyrrell et al. 2012), are often also opportunities for young people to re-negotiate their agency and contest adult-child hierarchies of power as these become temporally destabilised in transient contexts. While our arguments above place emotions at the heart of young people's links with places of departure and destination, it is equally important to consider the emotional constellations of movement itself and not reduce young migrants' subjectivities to being somewhere in-between the old and the new (Marcu 2012).

\section{Inequity}

Critical analyses of mobility both within and across national borders have highlighted the cultural and economic processes through which people are bounded, emplaced, permitted or forced to move as part of a broader politics of mobility (Cresswell, 2010; Salazar, 2017). This special issue indicates how examining mobility through the lens of youth puts into sharper focus the key point often subsumed under the rubric of a 'politics of mobility', namely the inequity of mobility. This is not to say that the ethical conundrums posed by mobility have not been addressed directly because they have, 
for instance in recent work on the interface between mobility, people, and technological infrastructure (e.g. Sager, 2017; Spahn, 2013). There is also a rich literature on ethics and immigration, which uses normative and applied ethics to question the right of states to control who to admit into 'their' territory (Fine, 2013; Seglow, 2005; Straehle and Lenard, 2012). However, we propose that youth, as a category of social difference and as social actors, can offer novel insights into the inequitable nature of mobility. 'Youth' relates to other categories of social difference, such as race, gender, sexual identities and class, which operate as organising principles that interact with social structures to shape young people's experiences and life chances.

Transnational movements operate within a highly unequal global landscape of freedom of movement, which goes hand in hand with extreme disparities in access to resources that impacts on the decisions and abilities to move (Mains et al., 2013, Esson, this issue). As Kunz argues, the privilege of transnational mobility is formed through "complex configurations of racialisation, gender, class and nationality, often involving problematic reproductions of the colonial past" (2016:89). However, age is curiously often absent from such interpretations, even though critical analyses of the so-called migration-development nexus place youth at its heart due to young people's dynamic strategies in securing livelihoods (Gough et al. 2013). Age certainly is a key factor for understanding the inequitable constellation of transnational mobility. On the one hand, young people's access to, and utilisation of, resources that enable transnational mobility might be relatively higher due to their dynamic embodied agency (Jeffrey, 2012), they may also be disproportionally targeted by the restrictive policing of transnational mobility (McLaughlin, 2018). Where spatial mobility can be seen by young people as a precursor for social 
mobility (Esson, 2015b), both aspects of mobility are ultimately circumscribed by a nexus of post-colonial and neoliberal regimes that curb global movement as well as access to economic resources and political liberties. Critical analyses of how such inequitable regimes lead to young people's mobility being read and governed have the capacity to advance theorical discussion of concepts such as 'agency' (Esson, this issue).

This global inequity operates under firmly entrenched contours of power and within complex networks of actors and migration management regimes, but its outcomes are not fixed. Indeed, there are cases of severe ruptures to mobility regimes and youth play a prominent role in those, as facilitators of change as well as the key subjects of the regulatory responses. One such example is the lifting of movement restrictions in Europe after the fall of the Iron Curtain. It was young people from Eastern Europe who took most advantage of the new opportunities of indeterminate intra-European migration (Burrell, 2009; King and Williams, 2018), but it is also mainly young people who will be impacted by the forthcoming ruptures of Brexit (Lulle et al. 2018), and other populist attempts to restrict intra-European mobility. Another example is the mobility triggered by climate change and environmental injustice, in which young people play a key role because of being knowledgeable about environmental threats and opportunities to move (Hugo, 2016) but also as targets of family expectations and strategic governmental arrangements to mitigate the impacts of environmental change (Baez et al, 2017). In both examples, access to resources to move and the pressure to move are changing drastically, and the inequities of these shifting arrangements and settings most prominently impact on young people. 
Youth are also centrally placed in inequities within countries, such as around the regional differentiations in resources to move (Azaola, 2010; Brown et al., 2017) or as subjects of multiple marginalisation, structural violence and socio-spatial injustice (Winton 2016). Papers in this special issue (Ní Laoire; Esson) suggest that transnational mobility should be understood in relation to other spatio-temporal patterns of mobility, such as the regional or everyday. This is because the management, coercion or policing of the mobility of some bodies unfolds from inequities within individual countries, through intersections of youth, gender, sexual identities, race and class (see also Collins et al. 2013). Examples include the surveillance policies that normalise the interrogation of non-White bodies in airport controls (Cole and Maisuria 2007), or familial strategies to encourage and facilitate the gendered movement of young people in response to economic opportunities (Bylander 2015; Punch 2015). Thus, examining young people's transnational mobilities brings to the fore - and advances - an analysis of the way inequities mobilise and immobilise particular bodies across space and time.

\section{Temporality}

A recognition of the emotional and inequitable dynamics within processes of mobility and the life-course reveals that temporality is virtually inseparable from discussions of both youth and migration. 'The temporal' denotes multiple facets of time: as a lived experience, as normatively ordered and ordering, as symbolically invoked, as a resource or a burden, as central to subjective biographies and social ideas of the lifecourse, as never universally experienced, and always entangled with the spatial (Cwerner, 2001, Griffiths et al. 2013, Page et al. 2017). Scholarship on youth and 
migration have questioned linear temporalities. Migration is no longer understood as a singular journey towards settlement, but rather an open-ended process. One that may include physical, emotional and social experiences of diversion, repetition, stasis and leaps forward (Kleist, 2018), and be shaped by collective pasts and future hopes. Youth is understood not as a defined stage in a linear 'development' from childhood to adulthood, but as an unstable and fluid social status produced by particular 'vital conjunctures' of social events, actions and collective projects (Johnson and Hanks, 2002).

Foregrounding temporality may afford new perspectives on young people's (im)mobilities. Attending to variables such as age at migration, and the frequency, duration and placement within the life-course of local and international moves has been proposed as a way to break out of the (methodologically) nationalist standpoints which plague the use of national, ethnic or 'generational' categorisations, and to reach new insights into the migrant experience (Erdal and Ezzati, 2015; van Geel and Mazzucato, 2017). Though we may critique the way that young people are inscribed with being bearers of the imagined future in co-ethnic or nation-building discourses (Mills and Duckett, 2015), this remains a potent social force, as it is through children [and young people] that a community's reproduction is actualised' (Coe et al., 2011:2). Papers in this issue (Daniels' et al., Ni Laoire, and Sirriyeh) attest to the way that working with the temporality of intergenerational relations, hopes, fears, fulfilments or frustrations can reveal much about migration drivers, moralities, and projects (Carling et al., 2012; Erdal and Ezzati, 2015; Ni Laoire, 2011). 
Furthermore, temporal perspectives can enhance our understandings of the lived experiences and socio-political contexts surrounding youthful (im)mobilties. Young people's migration desires within and from the Global South have been analysed as a response to 'waithood' (Honwana, 2014) or 'timepass' (Jeffrey, 2010). The sense of 'stuckness' in time in the life-course, surpluses of everyday time, and feeling left out of times of 'progress and modernity' are experienced by many young people, often linked to the devaluation of formal education and unemployment. Such temporal dynamics are produced by structural adjustments and historically-produced global economic inequities (Langevang and Gough, 2009; Esson, 2015a; Mains, 2007). Though freedom of movement is much greater for young people in the Global North, studies highlight also their mobility as a strategy of 'becoming someone', given that mobility bestows the cultural capital of being a modern, flexible, individualised subject (Eriksson, 2017; Frandberg, 2015, Cranston, this issue). This underlines that normative (though socio-culturally varied) ideas of progress through the time of the life-course remain central to producing youthful aspirations to mobility, though mobility may also represent 'being a modern youth' for a liminal period and be engaged to 'delay' as well as 'accelerate' becoming adult (Eriksson, 2017; Ungruhe, 2010; Franberg, 2015).

Rich work on migration and temporality also underscores how temporality is part of the politics surrounding migration and young lives. Discourses of temporal sameness and difference are central to the politics of inclusion and exclusion, as migrants and their descendants are often denied identification with the nation and its past (Çağlar, 2016). Time is also a direct mechanism of migration governance - for instance in 'temporary' visa regimes which not only delimit legality, but also construct the desirable migrant as young, self-reliant, and channelled into low paid and flexible 
labour. The precarity of these conditions is felt in embodied temporalities such as the work rhythms of long or nocturnal hours (Robertson, 2014, Kwon, 2018). Several scholars write evocatively of temporal uncertainty as 'a source of anguish and a tool of governmentality' (Griffiths, 2014, 2005), such as the way asylum seekers may face the 'sticky' or 'suspended' times of chronic waiting or indefinite detention, in paradoxical co-existence with the 'frenzied time' of deportation or visa requirements (Griffiths, 2014). For communities with precarious or undocumented status, the possibility of deportation extends through time in anxious anticipations and aftershocks (Drotbohm and Hasselberg, 2015; Boehm, 2009).

There is greater scope to put this rich literature on temporality and migration into closer conversation with work on youth. Some scholars have begun to do so, such as those examining how the transition out of public schooling in the US may entail 'learning to be illegal'. Undocumented youth in the US face legal blockages to employment, higher education and independence through restricted automobility, which results in a sense of being 'cut off from the futures they have been raised to expect' (Gonzalez, 2011, 616). Even where legal status is not a problem, wellintentioned spaces of 'integration' can lead to a sense of 'stuckness' for newly arrived young migrants. For instance, for young people required to undertake introductory language courses in Sweden repeatedly, disappointments around educational progress are exacerbated by the homogeneity of chronological age in schooling, and result in feelings of demotivation and being 'out of line' with the temporalities of those their own age in mainstream Swedish society (Nilsson Folke, 2017). Furthermore, young migrants may experience disorientation and difficulty around the differential availability of state support when they cross the hard temporal line between legally defined 'childhood' and adulthood (cf. Daniels et al., this issue). 
In summary, this editorial and special issue aim to highlight that emotion, inequity and temporality are fruitful thematics through which to advance analysis of youth and transnational mobility. We call for further explorations to be made of the multiple temporalities and emotions of youth and transnational mobility - beyond waiting and stuckness, or imagined hopes and futures. Furthermore, we contend that in considering how pasts, presents and futures are folded into one another in experiences of mobility and the life course (Page et al., 2017), work on transnational youth mobilities can be well positioned to extend scholarship on the dialectical nature of structure and agency. For instance, young people's aspirations to migrate may be conceived as desires that emerge and circulate through social and discursive assemblages (Carling and Collins, 2018; Collins, 2018), highlighting the situated, networked and partial nature of human agency. In closing, our conceptualisation of migrants' and young people's lives as constantly unfolding and becoming, shaped through connections to place, real and imagined, in dreams and memories (Shubin, 2015; Worth, 2009), moves academic debates towards an understanding of subjectivity in which materiality and emotion become central - but do so while being informed by questions of justice and inequity.

\section{References}

Adey, P. (2006). If mobility is everything then it is nothing: towards a relational politics of (im)mobilities. Mobilities, 1(1), 75-94. DOI: 10.1080/17450100500489080 
Ansell, N. (2009). Childhood and the politics of scale: descaling children's geographies? Progress in Human Geography, 33(2), 190 - 209. DOI:

$10.1177 / 0309132508090980$

Azaola, M.C. (2012). Becoming a migrant: aspirations of youths during their transition to adulthood in rural Mexico. Journal of Youth Studies, 15(7), 875-889.

DOI: $10.1080 / 13676261.2012 .677813$

Baez, J., Caruso, G., Mueller, V. \& Niu, C. (2017). Droughts augment youth migration in Northern Latin America and the Caribbean. Climatic Change, 140(3-4), 423-435. DOI: 10.1007/s10584-016-1863-2

Bailey, A. J. (2009). Population geography: lifecourse matters. Progress in Human Geography, 33(3), 407-418. DOI: 10.1177/0309132508096355

Baldassar, L. (2015). Guilty feelings and the guilt trip: Emotions and motivation in migration and transnational caregiving. Emotion, Space and Society, 16, 81-89. DOI: 10.1016/j.emospa.2014.09.003

Bauböck, R. (2009). The rights and duties of external citizenship. Citizenship Studies, 13(5), 475-499. DOI: 10.1080/13621020903174647

Barker, J., Kraftl, P., Horton, J., Tucker, F. (2009). The road less travelled - new directions in children's and young people's mobility. Mobilities, 4(1), 1-10. DOI: $10.1080 / 17450100802657939$

Beazley, H., Butt, L., Ball, J. (2018) 'Like it, don't like it, you have to like it': children's emotional responses to the absence of transnational migrant parents in Lombok, 
Indonesia. Children's Geographies, 16(6), 591-603. DOI:

$10.1080 / 14733285.2017 .1407405$

Blazek, M., Windram-Geddes, M. (2013). Editorial: Thinking and doing children's emotional geographies. Emotion, Space and Society, 9, 1-3. DOI:

10.1016/j.emospa.2013.07.006

Boccagni, P., Baldassar, L. (2015). Emotions on the move: Mapping the emergent field of emotion and migration. Emotion, Space and Society, 16, 73-80. DOI:

10.1016/j.emospa.2015.06.009

Boehm, D. A. (2009). “¿Quien Sabe?”: Deportation And Temporality Among Transnational Mexicans. Urban Anthropology and Studies of Cultural Systems and World Economic Development, 38(2/3/4), 345-374.

Brown, G. (2011). Emotional geographies of young people's aspirations for adult life. Children's Geographies, 9(1), 7-22. DOI: 10.1080/14733285.2011.540435

Brown, T., Scrase, T.J. \& Ganguly-Scrase, R. (2017). Globalised dreams, local constraints: migration and youth aspirations in an Indian regional town. Children's Geographies, 15(5), 531-544. DOI: 10.1080/14733285.2016.1274948

Burrell, K. (2009). Polish Migration to the UK in the 'New' European Union: After 2004. Ashgate, Farnham. DOI: 10.1080/14782804.2011.580927

Burridge, A. (2010). Youth on the line and the No Borders movement. Children's Geographies, 8(4), 401-411. DOI: 10.1080/14733285.2010.511005 
Bylander, M. (2015). Contested mobilities: gendered migration pressures among Cambodian youth. Gender, Place and Culture, 22(8), 1124-1140. DOI:

$10.1080 / 0966369 X .2014 .939154$

Çağlar, A. (2016). Still 'migrants' after all those years: foundational mobilities, temporal frames and emplacement of migrants. Journal of Ethnic and Migration Studies, 42(6), 952-969. DOI: 10.1080/1369183X.2015.1126085

Carling, J., \& Collins, F. (2018). Aspiration, desire and drivers of migration. Journal of Ethnic and Migration Studies, 44(6), 909-926. DOI:

10.1080/1369183X.2017.1384134

Carling, J., Menjívar, C., \& Schmalzbauer, L. (2012). Central themes in the study of transnational parenthood. Journal of Ethnic and Migration Studies, 38(2), 191-217. DOI: 10.1080/1369183X.2012.646417

Chakraborty, K. \& Thambiah, S. (2018). Children and young people's emotions of migration across Asia. Children's Geographies, 16(6), 583-590. DOI:

$10.1080 / 14733285.2018 .1503231$

Cheung Judge, R. (2015). Emotion, Volunteer-Tourism and Marginalised Youth. In: Blazek M., Kraftl P. (eds) Children's Emotions in Policy and Practice: Mapping and Making Spaces of Childhood. Palgrave Macmillan, London

Coe, C., Reynolds, R. R., Boehm, D. A., Hess, J. M., \& Rae-Espinoza, H. (2011). Everyday Ruptures: Children, Youth, and Migration in Global Perspective. Vanderbilt University Press. 
Cole, M. \& Maisuiria, A. (2007). 'Shut the $f^{\star * *}$ up', 'you have no rights here': Critical Race Theory and Racialisation in post-7/7 racist Britain. Journal for Critical Education Policy Studies, 5(1), 94-120.

Collins, F. L. (2018). Desire as a theory for migration studies: temporality, assemblage and becoming in the narratives of migrants. Journal of Ethnic and Migration Studies, 44(6), 964-980. DOI: 10.1080/1369183X.2017.1384147

Collins, F.L., Sidhu, R., Lewis, N., Yeoh B.S.A. (2014). Mobility and desire: international students and Asian regionalism in aspirational Singapore. Discourse: Studies in the Cultural Politics of Education, 35(5), 661-676. DOI: $10.1080 / 01596306.2014 .921996$

Collins, R., Esson, J., O'Neill Gutierrez, C., \& Adekunle, A. (2013). Youth in motion: Spatialising youth movement (s) in the social sciences. Children's Geographies, 11(3), 369-376. DOI: 10.1080/14733285.2013.779840 Conradson, D., McKay, D. (2007). Translocal subjectivities: mobility, connection, emotion. Mobilities, 2(2), 167-174. DOI: 10.1080/17450100701381524

Cresswell, T. (2010). Towards a politics of mobility. Environment and Planning D: Society and Space, 28 (1), 17-31. DOI: 10.1068/d11407

Crivello, G. (2015). 'There's no future here': The time and place of children's migration aspirations in Peru. Geoforum, 62, 38-46. DOI:

10.1016/j.geoforum.2015.03.016

Cwerner, S. B. (2001). The Times of Migration. Journal of Ethnic and Migration Studies, 27(1), 7-36. DOI: 10.1080/13691830125283 
Danic, I. (2012). The everyday occupation of space by teenagers in a deprived neighbourhood: conflict without mobilisation. Population, Space and Place, 18(5), 659-668. DOI: 10.1002/psp.1701

Datta, A. (2018). Pride and shame in the city: young people's experiences of ruralurban migration in India. Children's Geographies, 16(6), 654-665. DOI:

$10.1080 / 14733285.2018 .1495317$

Drotbohm, H., \& Hasselberg, I. (2015). Deportation, Anxiety, Justice: New Ethnographic Perspectives. Journal of Ethnic and Migration Studies, 41(4), 551-562. DOI: 10.1080/1369183X.2014.957171

Erdal, M. B., \& Ezzati, R. (2015). 'Where are you from' or 'when did you come'? Temporal dimensions in migrants' reflections about settlement and return. Ethnic and Racial Studies, 38(7), 1202-1217. DOI: 10.1080/01419870.2014.971041

Eriksson, M. (2017). Narratives of Mobility and Modernity: Representations of Places and People Among Young Adults in Sweden. Population, Space and Place, 23(2), e2002. DOI: 10.1002/psp.2002

Esson, J. (2015a). Escape to victory: Development, youth entrepreneurship and the migration of Ghanaian footballers. Geoforum, 64, 47-55. DOI:

10.1016/j.geoforum.2015.06.005

Esson, J. (2015b). You have to try your luck: male Ghanaian youth and the uncertainty of football migration. Environment and Planning A, 47(6), 1383-1397. DOI: $0.1177 / 0308518 \times 15594920$ 
Evans, R. (2011). Young caregiving and HIV in the UK: caring relationships and mobilities in African migrant families, Population, Space and Place, 17(4), 338-360. DOI: $10.1002 / p s p .583$

Findlay, A.M., King, R., Smith, F.M., Geddes, A., Skeldon, R. (2012). World class? An investigation of globalisation, difference and international student mobility. Transactions of the Institute of British Geographers, 37(1), 118-131. DOI: $10.1111 / \mathrm{j} .1475-5661.2011 .00454 . x$

Findlay, A., McCollum, D., Coulter, R., Gayle, V. (2015). New mobilities across the life course: a framework for analysing demographically linked drivers of migration. Population, Space and Place, 31(4), 390-402. DOI: 10.1002/psp.1956

Fine, S. (2013). The ethics of immigration: self-determination and the right to exclude. Philosophy Compass, 8(3), 254-268. DOI: 10.1111/phc3.12019

Francisco-Menchavez, V. (2018). Sukli: uneven exchanges of care work of children left behind in Filipino transnational families. Children's Geographies, 16(6), 604-615. DOI: $10.1080 / 14733285.2018 .1466028$

Frändberg, L. (2015). Acceleration or avoidance? The role of temporary moves abroad in the transition to adulthood. Population, Space and Place, 21(6), 553-567. DOI: 10.1002/psp.1851

Gardner, K., \& Mand, K. (2012). 'My Away is Here': Place, Emplacement and Mobility amongst British Bengali Children. Journal of Ethnic and Migration Studies, 38(6), 969-986. DOI: 10.1080/1369183X.2012.677177 
Geel, J. van, \& Mazzucato, V. (2018). Conceptualising youth mobility trajectories: thinking beyond conventional categories. Journal of Ethnic and Migration Studies, 44(13), 2144-2162. DOI: 10.1080/1369183X.2017.1409107

Gonzales, R. G. (2011). Learning to Be Illegal: Undocumented Youth and Shifting Legal Contexts in the Transition to Adulthood. American Sociological Review, 76(4), 602-619. DOI: $10.1177 / 0003122411411901$

Gough, K.V., Langevang, T., Owusu, G. (2013). Youth employment in a globalising world. International Development Planning Review, 35(2), 91-102. DOI: 10.3828/idpr.2013.7

Griffiths, M. B. E. (2014). Out of Time: The Temporal Uncertainties of Refused Asylum Seekers and Immigration Detainees. Journal of Ethnic and Migration Studies, 40(12), 1991-2009. DOI: 10.1080/1369183X.2014.907737

Griffiths, M., Rogers, A., Anderson, B. (2013). Migration, Time and Temporalities: Review and Prospect. COMPAS Research Resources Paper.

Holt, L., Costello, L. (2011). Beyond otherness: exploring diverse spatialities and mobilities of childhood and youth populations. Population, Space and Place, 17(4), 299-303. DOI: $10.1002 / p s p .621$

Honwana, A. (2014). 'Waithood': Youth Transitions and Social Change. Development and Equity, 28-40.

Hopkins, P., Pain, R. (2007). Geographies of age: thinking relationally. Area, 39(3), 287-294: DOI: 10.1111/j.1475-4762.2007.00750.x 
Horton, J., Kraftl, P. (2006). What else? some more ways of thinking and doing ‘Children's Geographies'. Children's Geographies, 4(1), 69-95. DOI: $0.1080 / 14733280600577459$

Hörschelmann, K. (2015). Divided emotions: children at war. In: Blazek M., Kraftl P. (eds) Children's Emotions in Policy and Practice: Mapping and Making Spaces of Childhood. Palgrave Macmillan, London

Hugo, G. (2011). Future demographic change and its interactions with migration and climate change. Global Environmental Change, 21(S1), S23-S33. DOI: 10.1016/j.gloenvcha.2011.09.008

Jeffrey, C. (2010). Geographies of children and youth I: Eroding maps of life. Progress in Human Geography, 34(4), 496-505. DOI: 10.1177/0309132509348533

Jeffrey, C. (2012). Geographies of children and youth II: Global youth agency. Progress in Human Geography, 36(2), 245-253. DOI: 10.1177/0309132510393316 Jeffrey, C. (2013). Geographies of children and youth III: Alchemists of the revolution? Progress in Human Geography, 37(1), 145-152. DOI: $10.1177 / 0309132511434902$

Johnson-Hanks, J. (2002). On the Limits of Life Stages in Ethnography: Toward a Theory of Vital Conjunctures. American Anthropologist, 104(3), 865-880. DOI: /10.1525/aa.2002.104.3.865

Khan, A.A. (2018). From the peaks and back: mapping the emotions of transHimalayan children education migration journeys in Kathmandu, Nepal. Children's Geographies, 16(6), 604-615. DOI: 10.1080/14733285.2018.1479732 
King, R. (2012). Geography and migration studies: retrospect and prospect. Population, Space and Place, 18(2), 134-153. DOI: 10.1002/psp.685

Kleist, N. (2018). Trajectories of involuntary return migration to Ghana: Forced relocation processes and post-return life. Geoforum. DOI: 10.1016/j.geoforum.2017.12.005

Kraftl, P. \& Blazek, M. (2015). Mapping and making spaces of childhood. In: Blazek M., Kraftl P. (eds) Children's Emotions in Policy and Practice: Mapping and Making Spaces of Childhood. Palgrave Macmillan, London.

Kunz, S. (2016). Privileged mobilities: locating the expatriate in migration scholarship. Geography Compass, 10(3), 89-101. DOI: 10.1111/gec3.12253

Langevang, T., \& Gough, K. V. (2009). Surviving through movement: the mobility of urban youth in Ghana. Social \& Cultural Geography, 10(7), 741-756. DOI: $10.1080 / 14649360903205116$

Leyshon, M. (2011). The struggle to belong: young people on the move in the countryside. Population, Space and Place, 17(4), 304-325. DOI: 10.1002/psp.580

Lulle, A., King, R., Dvorakova, V. \& Szkudlarek, A. (2018). Between disruptions and connections: 'new' EU migrants before and after the Brexit in the UK. Population, Space and Place, 25(1), e2200. DOI: 10.1002/psp.2122

Mains, D. (2007). Neoliberal times: Progress, boredom, and shame among young men in urban Ethiopia. American Ethnologist, 34(4), 659-673. DOI:

10.1525/ae.2007.34.4.659 
Mains, S.P., Gilmartin, M., Cullen, D., Mohammad, R., Tolia-Kelly, D.P., Raghuram, P., Winders, J. (2013). Postcolonial migrations. Social \& Cultural Geography, 14(2), 131-144. DOI: 10.1080/14649365.2012.753468

Marcu, S. (2012). Emotions on the move: belonging, sense of place and feelings identities among young Romanian immigrants in Spain. Journal of Youth Studies, 15(2), 207-223. DOI: 10.1080/13676261.2011.630996

McLaughlin, C. (2018). They don't look like children': child asylum-seekers, the Dubs amendment and the politics of childhood. Journal of Ethnic and Migration Studies, 44(11), 1757-1773. DOI: 10.1080/1369183X.2017.1417027

Mills, S., Duckett, J. (2015) Representing, reproducing, and reconfiguring the nation: geographies of youth citizenship and devolution. In: Kallio, K., Mills, S., Skelton, T. (Eds) Geographies of Children and Young People Vol. 7: Politics, Citizenship and Rights. Springer, New York.

Murray, L. \& Mand, K. (2013). Travelling near and far: placing children's mobile emotions. Emotion, Space and Society, 9, 72-79. DOI: 0.1016/j.emospa.2013.02.005

Ní Laoire, C. (2000). Conceptualising Irish rural youth migration: a biographical approach. Population, Space and Place, 6(3), 229-243. DOI: 10.1002/10991220(200005/06)6:3<229::AID-IJPG185>3.0.CO;2-R

Ni Laoire, C. (2011). Narratives of 'Innocent Irish Childhoods': Return Migration and Intergenerational Family Dynamics. Journal of Ethnic and Migration Studies, 37(8), 1253-1271. DOI: 10.1080/1369183X.2011.590928 
Ní Laoire, C., Carpena-Méndez, F., Tyrrell, N., White, A. (2010). Introduction: Childhood and migration - mobilities, homes and belongings. Childhood: Global Journal of Child Research, 17(2), 155-162. DOI: 10.1177/0907568210365463

Folke, J. N. (2018). Moving on or moving back? The temporalities of migrant students' lived versus imagined school careers. Journal of Ethnic and Migration Studies, 44(9), 1506-1522. DOI:1080/1369183X.2017.1329008

Mavroudi, E, Page, P. \& Christou, A., (2017). 'Introduction: from time to timespace and forward to time again in migration studies' in Timespace and International Migration. Edward Elgar Publishing: UK

Pilkington, H. \& Johnson, R. (2003). Peripheral Youth: Relations of Identity and Power in Global/Local Context. European Journal of Cultural Studies, 6(3), 259-283. DOI: $10.1177 / 13675494030063001$

Porter, G., Hampshire, K., Abane, A., Robson, E., Munthali, A., Mashiri, M., \& Tanle, A. (2010). Moving young lives: Mobility, immobility and inter-generational tensions in urban Africa. Geoforum, 41(5), 796-804. DOI: 10.1016/j.geoforum.2010.05.001

Pruitt, L., Berents, H. \& Munro, G. (2018). Gender and age in the construction of male youth in the European migration "crisis". Signs: Journal of Women in Culture and Society, 43(3), 687-709. DOI:

Punch, S. (2015). Youth transitions and migration: negotiated and constrained interdependencies within and across generations. Journal of Youth Studies, 18(2), 262-276. DOI: 10.1080/13676261.2014.944118 
Reynolds, T., \& Zontini, E. (2016). Transnational and diasporic youth identities: exploring conceptual themes and future research agendas. Identities, 23(4), 379391. DOI: $10.1080 / 1070289 X .2015 .1024129$

Robertson, S. (2014). Time and Temporary Migration: The Case of Temporary Graduate Workers and Working Holiday Makers in Australia. Journal of Ethnic and Migration Studies, 40(12), 1915-1933. DOI: 10.1080/1369183X.2013.876896

Robertson, S., \& Ho, E. L.-E. (2016). Temporalities, materialities and connecting locales: migration and mobility in Asia-Pacific cities. Journal of Ethnic and Migration Studies, 42(14), 2263-2271. DOI: 10.1080/1369183X.2016.1205804

Robertson, S., Harris, A., Baldassar, L. (2018). Mobile transitions: a conceptual framework for researching a generation on the move. Journal of Youth Studies, 21(2), 203-217. DOI: 10.1080/13676261.2017.1362101

Sager, A. (2017) Toward a Cosmopolitan Ethics of Mobility: The Migrant's-Eye View of the World. Palgrave MacMillan, London.

Salazar, N.B. (2018). Theorizing mobility through concepts and figures. Tempo Social, 30(2), 153-168. DOI: 10.11606/0103-2070.ts.2018.142112.

Schuster, L., \& Majidi, N. (2015). Deportation Stigma and Re-migration. Journal of Ethnic and Migration Studies, 41(4), 635-652. DOI: 10.1080/1369183X.2014.957174 Seglow, J. (2005). The ethics of immigration. Political Studies Review, 3(3), 317-334. DOI: $10.1111 / \mathrm{j} .1478-9299.2005 .00026 . x$ 
Shubin, S. (2015). Migration timespaces: a Heideggerian approach to understanding the mobile being of Eastern Europeans in Scotland. Transactions of the Institute of British Geographers, 40(3), 350-361. DOI: 10.1111/tran.12078

Spahn, A. (2013). Moralizing Mobility? Persuasive Technologies and the Ethics of Mobility. Transfers: Interdisciplinary Journal of Mobility Studies, 3(2), 108-115. DOI: 10.3167/TRANS.2013.030207

Straehle, C. \& Lenard, P.T. (2012). The ethics of migration: introduction. Journal of International Political Theory, 8(1-2), 118-120.

Tymczuk, A. (2013). The morality of transnationalism: children of Ukrainian labor migrants write about migration, homeland and abroad. Children's Geographies, 11(4), 490-503. DOI: 10.1080/14733285.2013.812310

Tyrrell, N., White, A., Ní Laoire, C., Carpena-Mendez, F. (Eds) (2012) Transnational Migration and Childhood. London, New York: Routledge.

Ungruhe, C. (2010). Symbols of success: Youth, peer pressure and the role of adulthood among juvenile male return migrants in Ghana. Childhood, 17(2), 259271. DOI: $10.1177 / 0907568210365753$

Uprichard, E. (2008). Children as 'being and becomings': children, childhood and temporality. Children and Society, 22(4), 303-313. DOI: 10.1111/j.10990860.2007.00110.x

Valentine, G. (2003). Boundary crossings: transitions from childhood to adulthood. Children's Geographies, 1(1), 37-52. DOI: 10.1080/14733280302186 
Van Mol, C., Timmerman, C. (2014). Should I stay or should I go? An analysis of the determinants of intra-European student mobility. Population, Space and Place, 20(5), 465-479. DOI: 10.1002/psp.1833

Waite, L., \& Cook, J. (2011). Belonging among diasporic African communities in the UK: Plurilocal homes and simultaneity of place attachments. Emotion, Space and Society, 4(4), 238-248. DOI: 10.1016/j.emospa.2010.08.001

Wells, K. (2017). What does a republican government with Donald Trump as President of the USA mean for children, youth and families? Children's Geographies, 15(4), 491-497. DOI: 10.1080/14733285.2017.1297034

Wessendorf, S. (2007). 'Roots Migrants': Transnationalism and 'Return' among Second-Generation Italians in Switzerland. Journal of Ethnic and Migration Studies, 33(7), 1083-1102. DOI: 10.1080/13691830701541614

White, A., Bushin, N. (2011). More-than-methods: learning from research with children in the Irish asylum system. Population, Space and Place 17(4), 326-337. DOI: $10.1002 / p s p .602$

Winton A. (2016) Violence, Borders, and Boundaries: Reframing Young People's Mobility. In: Ni Laoire C., White A., Skelton T. (eds) Movement, Mobilities, and Journeys. Geographies of Children and Young People, vol 6. Springer, Singapore. DOI: 10.1007/978-981-4585-93-4_4-2.Worth, N. (2009). Understanding youth transition as 'Becoming': Identity, time and futurity. Geoforum, 40(6), 1050-1060. DOI: 10.1016/j.geoforum.2009.07.007 
Zembylas, M. (2012). The politics of fear and empathy: emotional ambivalence in 'host' children and youth discourses about migrants in Cyprus. Intercultural Education, 23(3), 195-208. DOI: 10.1080/14675986.2012.701426 